\title{
OPTIMIZED HYPERVENTILATION PRESERVES 2,3-DIPHOSPHOGLYCERATE IN SEVERE TRAUMATIC BRAIN INJURY
}

\author{
Rayne Borges Torres ${ }^{1}$, Renato Giuseppe Giovanni Terzi², Antônio Luís Eiras Falcão ${ }^{3}$, \\ Nelci Fenalti Höehr', Venâncio Pereira Dantas Filho ${ }^{5}$
}

\begin{abstract}
ABSTRAT - Introduction: The concentration of 2,3-diphosphoglycerate (2,3-DPG/Hct) increases as a physiological occurrence to $\mathrm{pH}$ increase and hyperventilation. This response was tested in patients with severe traumatic brain injury (TBI). Method: The concentration of 2,3-DPG/Hct was measured daily for six days in eleven patients with severe TBI in need of optimized hyperventilation because of intracranial hypertension. Results: There was correlation between $\mathrm{pH}$ and the concentration of DPG/Hct. The concentration of 2,3-DPG/Hct remained predominantly within normal levels with slight increase in the sixth day of the study. The concentration of 2,3-DPG/Hct correlated significantly with measured partial pressure of oxygen that saturates $50 \%$ the hemoglobin of the blood (P50st), confirming the consistency of our data. Conclusion: The expected physiological response of a progressive increase in concentration of 2,3-DPG/Hct to hyperventilation was not observed. This fact may be explained by the intermittent and not sustained hyperventilation as dictated by the protocol of optimized ventilation.
\end{abstract}

KEY WORDS: 2,3-diphosphoglycerate, brain injury, traumatic brain injury, hyperventilation, mechanical ventilation.

\begin{abstract}
A hiperventilação otimizada preserva o 2,3-difosfoglicerato no traumatismo craniencefálico grave
RESUMO - Introdução: A concentração de 2,3-difosfoglicerato nos eritrócitos (2,3-DPG/Hct) aumenta como ocorrência fisiológica ao aumento do pH e à hiperventilação. Esta resposta foi testada em pacientes com traumatismo craniencefálico (TCE) grave. Método: A concentração de 2,3-DPG/Hct foi medida diariamente, durante seis dias, em 11 pacientes com TCE grave necessitando de hiperventilação otimizada por causa da hipertensão intracraniana. Resultados: Houve correlação entre o pH e a concentração de 2,3-DPG/ Hct. A concentração de 2,3-DPG/Hct permaneceu predominantemente dentro da normalidade, com ligeira tendência à elevação no sexto dia de estudo. Houve correlação entre a concentração de 2,3-DPG/Hct e a pressão parcial de oxigênio que satura $50 \%$ da hemoglobina (P50st), confirmando a consistência dos dados. Conclusão: A esperada resposta fisiológica de aumento progressivo da concentração de 2,3-DPG/ Hct não foi observada. Este fato pode ser explicado pela aplicação intermitente e não sustentada de hiperventilação, como ditado pelo protocolo clínico de ventilação otimizada.
\end{abstract}

PALAVRAS-CHAVE: 2,3-difosfoglicerato, traumatismo cerebral, lesão cerebral traumática, hiperventilação, ventilação mecânica.

The organic phosphate present in the red blood cell - 2,3-diphosphoglycerate (2,3-DPG) - exerts important function in oxygen transport. The increase of this phosphate in the red blood cell reduces the hemoglobin oxygen affinity, facilitating oxygen delivery to the tissues. On the other hand, a reduction of 2,3-DPG in blood promotes an opposite effect ${ }^{1,2}$. The main factors that regulate the concentration of 2,3-DPG in the red blood cell are changes in red cell $\mathrm{pH}$ and hypoxia ${ }^{3}$. The arterial blood carbon dioxide $\left(\mathrm{PaCO}_{2}\right)$ and, consequently, $\mathrm{pH}$ are altered by mechanical ventilation which has been used in some situations, such as the control of intracranial hypertension in patients with severe traumatic brain injury (TBI).

The fall in $\mathrm{PaCO}_{2}$ (hypocapnia) reduces cerebral blood flow and intracranial pressure ${ }^{4}$. Currently, systematic and indiscriminate hyperventilation in pa-

Campinas State University (UNICAMP) Campinas, São Paulo, Brazil (FCM/UNICAMP): ${ }^{1}$ Physical Therapist and Master of Science. Director, Graduate Course of Phisiotherapy, Faculdades Integradas de Patos, Patos PB, Brazil; ${ }^{2}$ Full Professor of Surgery, FCM/UNICAMP; ${ }^{3}$ Assistant Professor, FCM/UNICAMP and Head UTI - Hospital das Clínicas - UNICAMP; ${ }^{4}$ Assistant Professor, Clinical Pathology Department, FCM/UNICAMP; ${ }^{5}$ Assistant Professor, Bioethics and Neurosurgery, FCM and Hospital das Clínicas da UNICAMP. Neurosurgeon Hospital das Clínicas - UNICAMP. This Project was partially funded by FAPESP Grant 99/12920-8 and Grant 00/02498-6.

Received 5 March 2007, received in final form 22 May 2007. Accepted 28 June 2007. 
tients with TBI has been questioned ${ }^{5}$, but it has been used, in a more restricted way, monitoring the global brain metabolism. This has been done calculating the cerebral extraction of oxygen through continuous or intermittent sampling of the venous oxygen saturation of the jugular bulb vein. The coupling between the $\mathrm{PaCO}_{2}$ and the cerebral extraction of oxygen has been called optimized ventilation ${ }^{6,7}$.

It is known that the reduction of $\mathrm{PaCO}_{2}$ and, consequently, the increase in arterial $\mathrm{pH}$, increases the affinity of hemoglobin for oxygen, a possible factor interfering with oxygen delivery to the tissues of the injured brain. The hypothesis of the present study was that an increase in the concentration of 2,3-DPG in the red blood cell must occur as a physiological response to increased arterial $\mathrm{pH}$ induced by mechanical ventilation. Therefore, the objective was to measure $\mathrm{PaCO}_{2}$, arterial $\mathrm{pH}$, the concentration of 2,3-DPG and to calculate the partial pressure of oxygen that saturates $50 \%$ the hemoglobin of the blood (P50) of patients that suffered severe TBI and submitted to a protocol of optimized ventilation.

\section{METHOD}

The present study was carried out in the Intensive Care Unit of the Hospital das Clínicas da Universidade Estadual de Campinas, UNICAMP. The study was approved by the Hospital Research Ethics Committee and informed consent was obtained from the patient's legal representatives.

Eleven patients were included. Gender, age, Glasgow Coma Scale (GCS) on admission ${ }^{8}$, the cause of the head trau$\mathrm{ma}$, the presence or absence of associated lesions, the evaluation of the computerized tomography by the Marshall clas- sification $^{9}$ and the APACHE II score as well as the APACHE II calculated risk of death are displayed on Table.

All patients exhibiting focal lesion as well as those with gunshot injuries underwent surgery. All patients were intubated and on mechanical ventilation. Intracranial pressure was continuously monitored as well as respiratory mechanics, capnography and pulse oximetry. The pressure transducer of titanium tip CODMAN ${ }^{\circledR}$ (Johnson \& Johnson, Raynham, Me - USA) was placed in the brain parenchyma and was used to monitor intracranial pressure. Respiratory variables, capnography and oximetry were continuously recorded with a respiratory profile monitor $\mathrm{CO}_{2} \mathrm{SMOPlus}{ }^{\circledR}$ (Respironics/Novametrix/Dixtal, São Paulo - Brazil). The hemoglobin saturation of jugular bulb blood was continuously monitored with a 4F fiber optic oxymetric catheter BAXTER $^{\circledR}$ coupled to a VIGIILANCE ${ }^{\circledR}$ monitor (Baxter Health Care Corporation, Irvine, CA - USA) and/or in an intermittent way by hemo-oximetry measured in a blood sample collected from the same catheter, or from a $16 \mathrm{G}$ catheter INTRACATH $^{\circledR}$. A central venous catheter (superior vein cava) and a urinary bladder catheter were inserted. The correct location of the venous catheters was confirmed by radiography.

The patients were kept supine with the head elevated to 30 degrees and the cervical spine maintained rectified to prevent compression of the jugular vein.

It was attempted to keep the cerebral perfusion pressure (mean arterial pressure less intracranial pressure) always above $70 \mathrm{mmHg}$, with volume replacement and/or administered norepinephrine. Sedation was started with fentanyl associated to midazolam $(0.5 \mathrm{mg}$ of fentanyl and $75 \mathrm{mg}$ of midazolam in $250 \mathrm{~mL}$ of $5 \%$ glucose. Dripping started at 10 to $20 \mathrm{microdrops} / \mathrm{min}$, up to a sufficient dose to sedate, according to the individual response of each patient).

Mechanical ventilation was optimized to keep cerebral oxygen extraction between $24 \%$ to $42 \%$ whenever the in-

Table. Casuistics.

\begin{tabular}{|c|c|c|c|c|c|c|c|c|c|}
\hline & Gender & Age & GCS & TA & $\mathrm{AL}$ & $\mathrm{CT}$ & AP II & AP $\|(\%)$ & ICU death \\
\hline 1 & M & 26 & 7 & MT & No & DIII & 17 & 17 & Yes \\
\hline 2 & $\mathrm{~F}$ & 19 & 8 & FA & No & - & 23 & 34 & No \\
\hline 3 & M & 33 & 7 & $S P$ & No & DII & 13 & 14 & No \\
\hline 4 & $M$ & 25 & 6 & $\mathrm{FL}$ & No & Focal & 16 & 12 & No \\
\hline 5 & M & 19 & 7 & FA & No & - & 11 & 11 & Yes \\
\hline 6 & $M$ & 28 & 8 & RO & Yes & DIII & 26 & 44 & No \\
\hline 7 & $M$ & 49 & 6 & $A U$ & No & DIV & 22 & 31 & Yes \\
\hline 8 & M & 23 & 6 & $A U$ & No & DIII & 17 & 17 & No \\
\hline 9 & M & 19 & 8 & $A U$ & No & DIV & 16 & 15 & No \\
\hline 10 & M & 15 & 8 & $A U$ & Yes & DIII & 22 & 30 & No \\
\hline 11 & $M$ & 25 & 8 & RO & Yes & DIV & 12 & 9 & No \\
\hline Mean & & 25.5 & 7.2 & & & & 17.7 & 21.34 & $3 / 11$ \\
\hline SD & & 9.3 & 0.9 & & & & 4.9 & 11.4 & \\
\hline
\end{tabular}

M, male; F, female; GCS, Glasgow Coma Scale; TA, type of accident; MT, motorcycle; FA, firearm; SP, spanking; FL, fall; RO, running over; AU, automobile; AL, associated lesions; CT, computadorized tomography (Marshall classification); DII, diffuse II; DIII, diffuse III; DIV, diffuse IV; AP II, APACHE II Score; AP II (\%), APACHE II Risk of death; ICU, intensive care unit. 
tracranial pressure was above $20 \mathrm{cmH}_{2} \mathrm{O}^{6,7}$. If the intracranial pressure remained elevated, mannitol $20 \%$ was given in bolus $(0.5$ a $1 \mathrm{~g} / \mathrm{kg} /$ dose) or the sedation was substituted by thionembutal (initial dose between 0.5 to $2 \mathrm{mg} / \mathrm{kg} /$ hour up to a maximum of $4 \mathrm{mg} / \mathrm{kg} / \mathrm{hour}$ ). If after these isolated or combined alternative procedures, the intracranial pressure remained elevated, a new brain computerized tomography was performed to evaluate the necessity of surgical decompression. No patient in this series needed surgical decompression.

The use of mannitol, furosemide and vasoactive drugs was recorded. Daily water balance and urine output was also registered.

Laboratory data - Arterial and venous blood gases as well as hemo-oximetry of the jugular bulb were performed daily and analyzed by the $A B L 700^{\circledR}$ (Radiometer, Copenhagen, Denmark). The calculation of the partial pressure of the oxygen that saturates $50 \%$ of the hemoglobin corrected to standard condition (temperature $37^{\circ} \mathrm{C}, \mathrm{pH} 7.4$ and $\mathrm{PaCO}_{2} 40 \mathrm{mmHg}$ ) (P50st) was obtained directly from the venous blood gas analysis. The concentration of 2,3-diphosphoglycerate per hematocrit (2,3-DPG/Hct) was measured by spectrophotometry, using the kit catalogue 665 of SIGMA DIANOSTIC (Sigma-Aldrich - St. Louis, Me - USA). The first measurement was collected from the arterial blood in the first 12 hours of hospital admission. The remainders were performed daily, always in the morning. Serum phosphate was measured in the Hospital auto-analyzer with "Roche Diagnostics" reagents. Collection of data was performed for six days after admission to the Intensive Care Unit (ICU). The normal range of phosphate for our hospital laboratory is 2.5 to $4.5 \mathrm{mg} / \mathrm{dL}$. Values below $2 \mathrm{mg} / \mathrm{dL}$ were considered as hypophosphatemia and values below $1 \mathrm{mg} /$ $\mathrm{dL}$ were considered as severe hypophosphatemia.

Standardization of the measure of the 2,3-DPG - One milliliter of blood was harvested in syringe daily (Peak 70, Medical Radiometer, Copenhagen, Denmark) and transported to the laboratory in a cooled container. The maximum period of refrigerated storage before analysis was two hours.

The 2,3-DPG reagents for quality control were catalogue S 3006 (normal) and catalogue S 3005 (high) of SIGMA DIAGNOSTIC (Sigma-Aldrich - St. Louis, Me - USA). The values read with the high control and the normal control were always between the limits, 3.3 to 4,3 and 1.7 to 2.5 $\mu \mathrm{mol} / \mathrm{ml}$, respectively, as required by the manufacturer.

Control group - Peripheral venous blood was collected from healthy not-smokers volunteers ( 20 men and 20 women) to establish our standard of normality. In these samples we measured the concentration of 2,3-DPG/Hct, serum phosphate and calculated P50st, with the same techniques described for the group of patients with TBI.

Statistical analysis - To compare and correlate the variables that had more than one measurement in each patient we applied the GEE analyses - generalized estimating equations, an extension of generalized linear models ${ }^{10}$. This analysis takes into consideration measurements obtained in the same patient at different times (longitudinal measurements) and analyses the simultaneous change on several variables in the same patient and in the patients' group. Continuous variables as well as categorical variables used in this analysis were classified by pre-determined cut values. Statistical significance was established as 0.05 .

\section{RESULTS}

Control group - The values of mean and standard deviations of the concentration of 2,3-DPG/Hct and serum phosphate, as well as the calculated P50st in the control group were $4.6 \pm 0.7 \mu \mathrm{mol} / \mathrm{mL}, 3.15 \pm 0.46$ $\mathrm{mg} / \mathrm{dL}$ and $26.3 \pm 1.0 \mathrm{mmHg}$, respectively. The values of the concentration of 2,3-DPG/Hct were within the limits of normality by the manufacturer standard and the values of the concentration of serum phosphate were within the limits of standardized normality for the Hospital Laboratory. The values of P50st are similar to those reported in the literature.

\section{Patients group}

Correlation between $\mathrm{pH}$ and $\mathrm{PaCO}_{2}$ - As previously mentioned, the means of $\mathrm{PaCO}_{2}$ and arterial $\mathrm{pH}$ were correlated through a GEE analysis $(p=0.0001)$. The values of mean $\mathrm{PaCO}_{2}$ and mean $\mathrm{pH}$ meet predominantly below $35 \mathrm{mmHg}$ and above 7.45 , respectively. This indicates that the patients had been, most of the time, kept in a state of respiratory alkalosis. At times, however, the value of $\mathrm{pH}$ is normal, despite a low $\mathrm{PaCO}_{2}$ and in some the value of $\mathrm{pH}$ is elevated

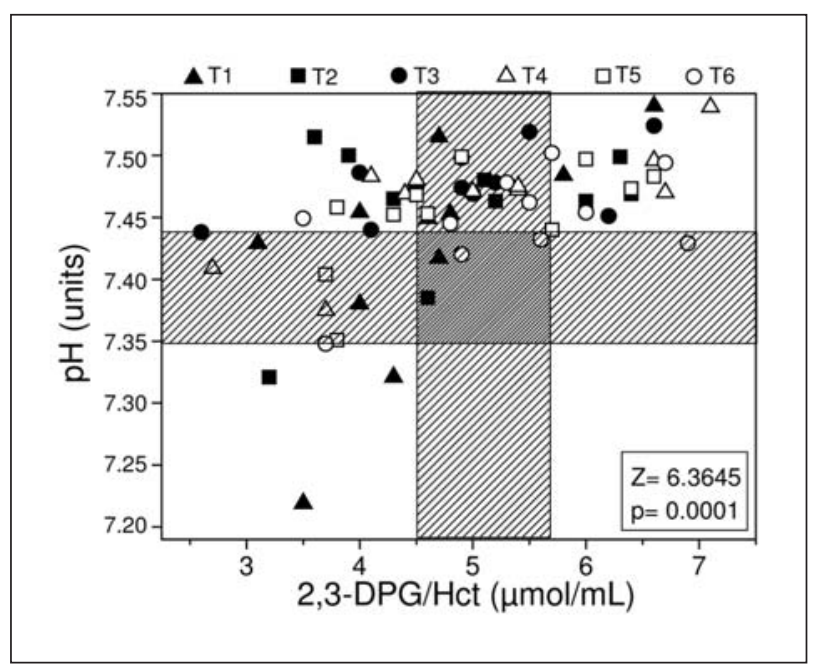

Fig 1. Correlation between the concentration of 2,3-DPG/Hct and the daily mean $\mathrm{pH}$ of each patient measured at different times. Each bullet represents a different time (from day 1 to day 6). The tread area delimits the normal values of the concentration of 2,3-DPG/Hct (3.9-5.3 $\mu \mathrm{mol} / \mathrm{mL})$ and/or $\mathrm{pH}$ (7.357.45). 


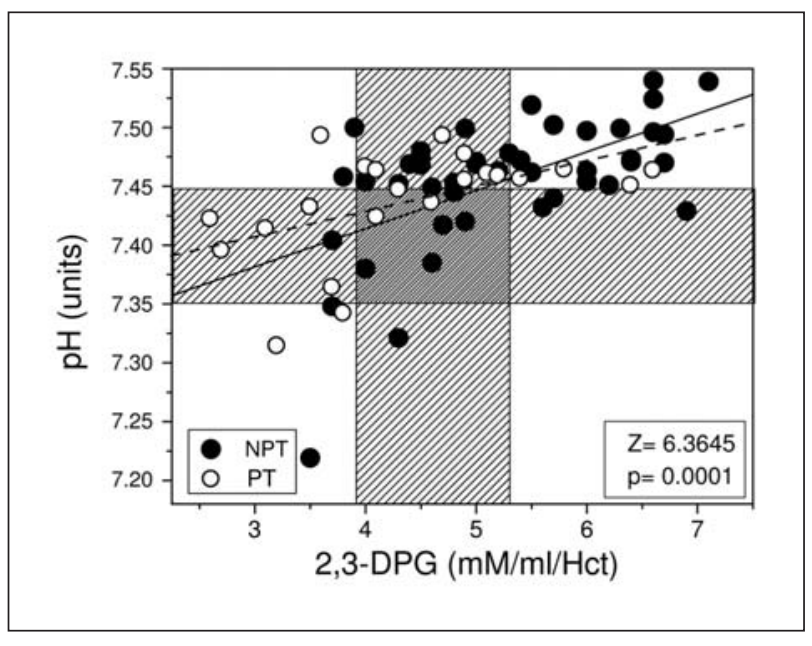

Fig 2. Correlation between the concentration of 2,3-DPG/Hct and the mean arterial $\mathrm{pH}$ for each patient. The solid circles (NPT) are measures in patient not transfused in the previous day and/or a phosphatemia above $2.0 \mathrm{mg} / \mathrm{dL}$. The open circles are samples collected from patients transfused in the previous day and/or with hypophosphatemia (Pi<2.0 mg/dL). The dotted line represents the correlation of the PT samples and the continuous line the NPT samples. The tread area delimits the normal values of the concentration of 2,3-DPG/Hct (3.9-5.3 $\mu \mathrm{moll}$ $\mathrm{ml}$ ) and/or $\mathrm{pH}$ (7.35-7.45).

despite a normal $\mathrm{PaCO}_{2}$. This situation was interpreted as an associated metabolic alteration (compensatory metabolic acidosis and primary metabolic alkalosis, respectively).

Correlation between the $\mathrm{pH}$ and the concentration of 2,3-DPG/Hct - A positive correlation between the mean arterial $\mathrm{pH}$ and the concentration of 2,3DPG/Hct was demonstrated through GEE analysis $(p=0.0001)$ (Fig 1).

Blood transfusion, hypophosphatemia and 2,3DPG/Hct - The concentration of 2,3-DPG/Hct was lower when the patients received stocked red blood cell transfusion within the 24 hours that preceded blood collection $(p=0.001)$ and/or presented a serum phosphate below $2.0 \mathrm{mg} / \mathrm{dL}$ (hypophosphatemia) $(p=$ $0.005)$. The interference of these factors on the correlation between $\mathrm{pH}$ and the concentration of 2,3DPG/Hct can be appreciated in Fig 2 .

2,3-DPG/Hct in relation to the time - The concentration of 2,3-DPG/Hct, remained normal from the first to the sixth day with a slight, non significant rise at day 6 (Fig 3) when the value of reference was the mean of the first day $(p=0.05)$ or the mean of the control group $(p=0.09)$.

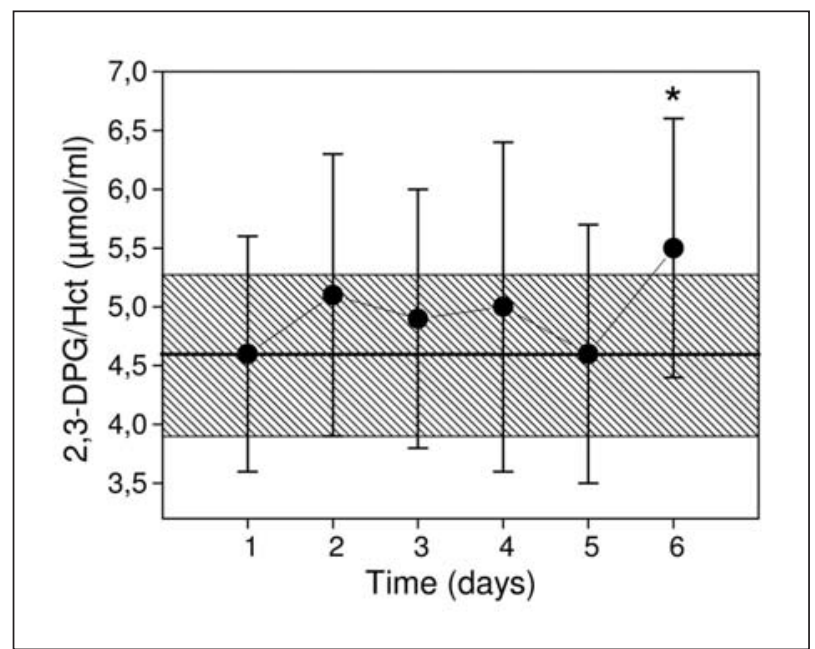

Fig 3. Mean and standard deviation of 2,3-DPG/Hct concentration over time for all patients. The tread area delimits the mean and standard deviation of the control group $(4.6 \pm 0.7$ $\mu \mathrm{mol} / \mathrm{mL}$ ). $p=0.05$ (compared with the first day) and $p=0.09$ (compared with the control group).

Correlation between the concentration of 2,3DPG/Hct and the P50st - As expected, a significant correlation was found comparing the concentration of 2,3-DPG/Hct and P50st ( $p=0.0001)$.

\section{DISCUSSION}

The data of the present study show a positive correlation between the arterial blood $\mathrm{pH}$ and the concentration of 2,3-DPG/Hct in patients with severe TBI artificially ventilated (Fig 1). Changes in 2,3-DPG as a response to $\mathrm{pH}$ variations had previously been reported in other physiological and clinical situations. In elevated altitudes, the increase of the concentration of 2,3-DPG in the erythrocytes has been interpreted as a compensating mechanism for oxygen transport at low barometric pressure ${ }^{11}$. In this situation, respiratory alkalosis seems to be the main cause to increase the concentration of 2,3-DPG in the red cells. Corresponding change in 2,3-DPG concentration in the red cells secondary to alteration in arterial blood $\mathrm{pH}$, either as metabolic or respiratory alkalosis or acidosis, have been reported in some clinical situations ${ }^{12,13}$. As a matter of fact, Bellingham et al..$^{14}$ confirmed experimentally this correlation, inducing metabolic alkalosis or acidosis in healthy volunteers.

The time and the depth of the alteration of $\mathrm{pH}$ to cause a significant response in the concentration of 2,3-DPG are not clear-cut in the literature. Venuxem et al. ${ }^{13}$ demonstrated changes in the concentration of 2,3-DPG only in chronic states of acidosis or alkalosis, because in acute situations $\mathrm{pH}$ changes within 
24 to 48 hours), the concentration of 2,3-DPG was normal. On the other hand, Bellingham et al. ${ }^{14} \mathrm{dem}-$ onstrated that the concentration of 2,3-DPG does not change within the first four hours of metabolic acidosis or metabolic alkalosis. However, a significant response was shown to occur after 48 hours. Respiratory alkalosis induced by hyperventilation in healthy volunteers, did not exhibit deviation in the red cell 2,3-DPG concentration ${ }^{15}$. However, in these subjects hyperventilation was not sustained for more than twenty minutes. In the current study, the time and the depth of the hyperventilation varied, from minutes to hours, according to the attending physician's orders based on the clinical situation of the patient. Nevertheless, the mean daily arterial pH remained elevated (moderate alkalosis) during the six days of the study in the majority of the patiente. Yet, the concentration of 2,3-DPG/Hct, exhibited great daily variation from patient to patient, with a mean, non significant rise by the sixth day (Fig 3). We attribute this finding to the intermittent and non sustained hyperventilation applied to these patients with severe TBI based on a previously established protocol of optimized ventilation.

For many years, systematic and indiscriminate hyperventilation has been used to prevent intracranial hypertension in patient victims of severe $\mathrm{TBI}^{16}$. $\mathrm{PaCO}_{2}$ was, systematically, kept between 20 and $30 \mathrm{mmHg}$. From the decade of 1980, the indiscriminate use of hyperventilation started to be criticized, because the reduction of cerebral blood flow induced by hypocapnia could lead, or exacerbate, post-traumatic brain ischemia. Currently, hyperventilation is no longer used prophylactically in the treatment of severe $\mathrm{TB} \mathrm{I}^{17}$. However, in refractory intracranial hypertension, hyperventilation may be cautiously applied under strict evaluation of cerebral oxygen extraction. This is currently done measuring the hemoglobin oxygen saturation in the jugular bulb, indirectly expressing cerebral blood flow. Hyperventilation is then titrated to keep oxygen extraction within safe limits, a practice called optimized ventilation ${ }^{6,7}$.

As respiratory alkalosis displaces the oxygen dissociation curve to the left (low P50st), the increased hemoglobin affinity for oxygen may hamper tissue availability. Therefore, the expected physiological response would be the return of the dissociation curve to normal (P50 normal, around $26.6 \mathrm{mmHg}$ ). In the current study, the expected gradual increase in the concentration of 2,3-DPG/Hct in response to hyperventilation (respiratory alkalosis) was not observed. This was attributed to the fact that hyperventilation was applied intermittently and based on an established protocol of optimized ventilation.

Other factors that may have contributed to the lack of response of 2,3-DPG/Hct must be mentioned. First, it is known that preserved blood has a progressive reduction in the levels of 2,3-DPG/Hct related to the time of Blood Bank storage. Five of the eleven patients in the present study received blood transfusion. All together they received 18 units of packed red cell. These units had been stocked for more than six days; two units were stocked for 18 days and 11 units for more than 20 days in the Hospital Blood Bank. Each patient transfused, received two or more units of packed red cells. These units were preserved with citrate-phosphate-dextrose-adenine (CPDA-1), that permits blood transfusion after 35 days of Blood Bank storage. Measured concentration of 2,3-DPG in blood preserved with the CPDA-1 show discrepancies on the weekly reduction of 2,3-DPG. A loss of $2,3-D P G$ around $40 \%$ to $60 \%$ occurs in the second week, from $70 \%$ to $90 \%$ in the third week and greater than $90 \%$ from the fourth week on ${ }^{18-21}$. In healthy volunteers, Heaton et al. evaluated, the restoration of 2,3-DPG in erythrocytes after blood transfusion, with Blood Bank storage of 35 days. When CPDA-1 was used the as conservative, they describe an important fall in the concentration of $2,3-\mathrm{DPG} / \mathrm{Hb}^{22}$. After a period of seven hours, $50 \%$ of the concentration of 2,3-DPG already had been restored, but the complete restoration was seen only after 48 hours.

A second factor that may interfere with 2,3-DPG production is hypophosphatemia. The reduction of serum phosphate can cause a fall in 2,3-DPG because of decreased 1,3-DPG, as well as increased degradation of 2,3-DPG ${ }^{22}$. The normal levels of serum phosphate lay between 2.5 and $4.5 \mathrm{mg} / \mathrm{dL}$. The clinical symptoms of hypophosphatemia are observed when serum phosphate falls below of $2.0 \mathrm{mg} / \mathrm{dL}^{23}$. In the analysis of our data, hypophosphatemia was defined when serum phosphate was under $2.0 \mathrm{mg} / \mathrm{dL}$. Hypophosphatemia has been described in patients with $\mathrm{TB}^{24-26}$. In the current study, the concentration of 2,3DPG/Hct was lower than normal when hypophosphatemia was present. Pas'ko and Volosheniuk ${ }^{25}$ also correlated serum phosphate, with the concentration of 2,3-DPG and ATP in the red cell. Hypophosphatemia may occur for several reasons in critical patients when associated to conditions such as alkalosis, the use of diuretics, volume expansion and sepsis ${ }^{27-29}$. However, marked hypophosphatemia has been seen only when hyperventilation is associated the intravenous glucose administration. The shift of phosphate from 
the blood to the cell across the cell membrane is attributed the two mechanisms. The first is the increase in glycolitic activity in response to the increase of intracellular $\mathrm{pH}$, induced by respiratory alkalosis. The second is the level of insulin in the bloodstream in response to glucose infusion, promoting greater migration of phosphate into the cell ${ }^{27}$. Recently, in healthy volunteers, it has been demonstrated that the longer the time of hyperventilation, or the deeper the hypocapnia, greater is the fall in serum phosphate ${ }^{15}$. In patients with severe TBI, Pas'ko and Volosheniuk ${ }^{25}$ had demonstrated that serum phosphate was lower in patients with hypocapnia. Hypophosphatemia in these patients was attributed to the insufficient replacement of phosphate in parenteral nutrition, as well as a loss of phosphate in the urine. Sepsis is another well described cause of hypophosphatemia and is associated to increased risk of death ${ }^{29,30}$. We reported that in 14 patients with severe TBI, a preliminary and partial analysis revealed an inverse relationship between the $\mathrm{pH}$ and serum phosphate. Furthermore, the most important factor leading to hypophosphatemia was sepsis. In addition, it was observed that serum phosphate was significantly lower in patients that died compared to survivors ${ }^{30}$.

Concluding, the variations in the concentration of 2,3-DPG/Hct observed in this group of patients with severe TBI exhibited a significant correlation with P50st $(p<0.05)$. This correlation of two independently measured variables certifies the reliability and the consistency of our data. It was not possible to demonstrate a gradual increase of the concentration of 2,3-DP/Hct in the course of the treatment with optimized hyperventilation. Despite the daily averages of all patients, pointing to respiratory alkalosis (high pH and low $\mathrm{PaCO}_{2}$ ) alkalosis was not sustained during all the period of study.

One limitation of this study is the absence of a comparative group with systematic and continuous hyperventilation. It is quite possible that the expected increase in 2,3-DPG/Hct could then be demonstrated. However, with basis on the present knowledge and current practice, it would have been unethical a study design including this group. Despite this constraint, our data suggest that optimized ventilation is a safe practice that does not interfere significantly, with P50st and ultimately, with oxygen delivery. Furthermore, it was possible to demonstrate a statistical correlation between arterial $\mathrm{pH}$ and the concentration of 2,3-DPG/Hct. Finally, we were able to demonstrate that blood transfusion and hypophosphatemia are adjuvant factors that may contribute to hinder the rise of 2,3-DPG/Hct.

\section{REFERENCES}

1. Benesch R, Benesch RE. Intracellular organic phosphates as regulators of oxigen release by hemoglobin. Nature 1969;221:618-622.

2. Chanutin A, Curnish RR. Effect of organic and inorganic phophastes on the oxygen equilibrium of human erytrocyte. Arch Biochem Biophys 1967;121:96.

3. Duhm J, Gerlach E. On the mechanisms of the hypoxia-induced increase of 2,3-diphosphoglycerate in erythrocytes: studies on rat erythrocytes in vivo and on human erythrocytes in vitro. Pflugers Arch 1971;326:254-269.

4. Lundberg N, Kjallquist A, Bien C. Reduction of increased intracranial pressure by hyperventilation: a therapeutic aid in neurological surgery. Acta Psychiatr Scand 1959;34(Suppl 139):S1-S64.

5. Muizelaar JP, Marmarou A, Ward JD, et al. Adverse effects of prolonged hyperventilation in patients with severe head injury: a randomized clinical trial. J Neurosurg 1991;75:731-739.

6. Cruz J. Relevance of ventilatory optimization in acute intracranial hypertension: a clinical, physiological, and therapeutic approach. Arq Neuropsiquiatr 1995;53:131-140.

7. Falcao A, Araujo S, Dragosavac D, et al. Cerebral hemometabolism: variability in the acute phase of traumatic coma. Arq Neuropsiquiatr 2000;58:877-882.

8. Teasdale G, Jennet B. Assessment of coma and impared consciosness. Lancet 1974;7:81-84.

9. Marshall LF, Marshall SB, Klauber MR et al. A new classification of head injury based on computerized tomography. J Neurosurg 1991;75(Suppl):S14-S20.

10. Zeger SL, Liang KY. Longitudinal data analysis for discrete and continuous outcomes. Biometrics 1986;42:121-130.

11. Samaja M, Brenna L, Allibardi S, Cerretelli P. Human red blood cell aging at 5,050-m altitude: a role during adaptation to hypoxia. J Appl Physiol 1993;75:1696-1701.

12. Carlone S, Serra P, Farber MO, et al. Red blood cell alkalosis and decreased oxyhemoglobin affinity. Am J Med Sci 1982;284:8-16.

13. Vanuxem D, Fornaris E, Delpierre S, Grimaud C. Role of the acid-base status on the changes of haemoglobin oxygen affinity in arterial hypoxemia (author's transl). Bull Physiopathol Respir (Nancy) 1975;11:305-314.

14. Bellingham AJ, Detter JC, Lenfant C. Regulatory mechanisms of hemoglobin oxygen affinity in acidosis and alkalosis. J Clin Invest 1971;50:700-706

15. Paleologos M, Stone E, Braude S. Persistent, progressive hypophosphataemia after voluntary hyperventilation. Clin Sci (Lond) 2000;98:619-625.

16. Backer DP, Gardner S. Intensive management of head injury. In Wilkins RH, Rengachary SS (Eds). Neurosurgery. New York: McGraw-Hill, 1985: 1593-1599.

17. Guidelines for the management of severe head injury. Brain Trauma Foundation, American Association of Neurological Surgeons, Joint Section on Neurotrauma and Critical Care. J Neurotrauma 1996;13:641-734.

18. Kreuger A, Akerblom O, Hogman CF. A clinical evaluation of citratephosphate-dextrose-adenine blood. Vox Sang 1975;29:81-89.

19. Moore GL, Ledford ME, Brummell MR. Red cell ATP and 2,3-diphosphoglycerate concentrations as a function of dihydroxyacetone supplementation of CPD adenine. Vox Sang 1981;41:11-17.

20. Moroff G, Dende D. Characterization of biochemical changes occurring during storage of red cells. Comparative studies with CPD and CPDA1 anticoagulant-preservative solutions. Transfusion 1983;23:484-489.

21. Heaton A, Keegan T, Holme S. In vivo regeneration of red cell 2,3-diphosphoglycerate following transfusion of DPG-depleted AS-1, AS-3 and CPDA-1 red cells. Br J Haematol 1989;71:131-136.

22. Larsen VH, Waldau T, Gravesen H, Siggaard-Andersen O. Erythrocyte 2,3-diphosphoglycerate depletion associated with hypophosphatemia detected by routine arterial blood gas analysis. Scand J Clin Lab Invest Suppl 1996;224:83-87.

23. Aubier M, Murciano D, Lecocguic $Y$, et al. Effect of hypophosphatemia on diaphragmatic contractility in patients with acute respiratory failure. N Engl J Med 1985;313:420-424.

24. King LR, Knowles HC Jr, Mclaurin RL. Calcium, phosphorus, and magnesium metabolism following head injury. Ann Surg 1973;177:126-131.

25. Pas'ko SA, Volosheniuk TG. [Disordered phosphorus metabolism and its correction in the acute period of severe craniocerebral trauma]. $\mathrm{Zh}$ Vopr Neirokhir Im N N Burdenko 1990;3:14-16.

26. Polderman KH, Bloemers FW, Peerdeman SM, Girbes AR. Hypomagnesemia and hypophosphatemia at admission in patients with severe head injury. Crit Care Med 2000;28:2022-2025.

27. Brautbar N, Leibovici H, Massry SG. On the mechanism of hypophosphatemia during acute hyperventilation: evidence for increased muscle glycolysis. Miner Electrolyte Metab 1983;9:45-50.

28. Weisinger JR, Bellorin-Font E. Magnesium and phosphorus. Lancet. 1998;352:391-396.

29. Barak V, Schwartz A, Kalickman I, et al. Prevalence of hypophosphatemia in sepsis and infection: the role of cytokines. Am J Med 1998;104: 40-47.

30. Torres RB, Terzi RGG, Falcão ALE, Hôer NF, Dantas Filho VP. Hypophosphatemia in severe traumatic brain injury. RBTI 2005;17:116-120. 